\title{
Effect of Freezing on Some Plant Toxins and Micronutrients in the Leaves of Amaranthus Cruentus
}

\author{
Amanabo Musa (Corresponding author) \\ Department of Biochemistry, Faculty of Natural Sciences \\ Ibrahim Badamasi Babangida University, Lapai, Niger State, Nigeria \\ Tel: 234-803-488-4031Ｅ-mail:musaamanabo@gmail.com; \\ Emmanuel O. Ogbadoyi \\ Department of Biochemistry/Global Institute for Bioexploration \\ Federal University of Technology, Minna, Nigeria
}

Received: January 25, 2013

Accepted: June 5, 2013 Published: June 5, 2013

doi:10.5296/jfs.v2i1.3141

URL: http://dx.doi.org/10.5296/jfs.v2i1.3141

\begin{abstract}
Postharvest handling is one of the major factors affecting the chemical contents of vegetables after harvesting. It is for this reason that the study was conducted to determine the influence of freezing on some plant toxins (cyanide, nitrate, soluble and total oxalates) and micronutrients which include vitamins ( $\beta$-carotene and vitamin $\mathrm{C})$ and mineral elements $(\mathrm{Fe}$, $\mathrm{Cu}, \mathrm{Mg}, \mathrm{Na}$ and $\mathrm{K}$ ) in Amaranthus cruentus. The results showed that the concentrations of vitamin $\mathrm{C}, \beta$-carotene, $\mathrm{K}$, cyanide, soluble and total oxalates in Amaranthus cruentus decreased significantly $(\mathrm{p}<0.05)$ during one week of freezing and they remained significantly unchanged in the second, third and fourth weeks of freezing. Except that the concentration of $\beta$-carotene in the fourth weeks was significantly lower than the second weeks of freezing. The decreasing effect of freezing on nitrate concentration in Amaranthus cruentus was not significant during the first week of storage, however, its concentration decreased significantly $(\mathrm{p}<0.05)$ in the second weeks and the value remained significantly unchanged for the third and fourth weeks of freezing. The significant decreased in the concentrations of $\mathrm{Fe}$ and $\mathrm{Cu}$ during freezing was observed during three weeks of freezing and remained significantly unchanged in the fourth weeks of storage. Similarly the concentrations
\end{abstract}




\section{Macrothink}

Journal of Food Studies ISSN 2166-1073 2013, Vol. 2, No. 1

of $\mathrm{Mg}$ and $\mathrm{Na}$ in Amaranthus cruentus decreased significantly $(\mathrm{p}<0.05)$ during two weeks of freezing and remained significantly unchanged in the third and fourth weeks. The results conclude that although freezing significantly reduced the antinutrients and toxic substances in Amaranthus cruentus it has a deleterious effects on the micronutrients content of the vegetable.

Keywords: Amaranthus cruentus, Plant toxins, Micronutrients, Vitamins, Minerals, Freezing 


\section{Introduction}

Amaranthus cruentus is an important leafy vegetable, grown throughout the temperate and tropical regions of the world. It is an herbaceous annual leafy vegetable that can be produced for fresh market in 4 - 6 weeks after planting (Schippers, 2000). The vegetable can be produced all the year round depending on the availability of water. Amaranthus cruentus requires loamy to sandy loam soil for good yield and does well in soils with high organic matter content (Grubben, 1986). There are about 60 species of Amaranthus and several of them are cultivated as leafy vegetables, cereals or ornamental plants (Schippers, 2000; He, 2002; Dhellot et al., 2006). The leaves of amaranthus combined with condiments are used to prepare sauce in Africa (Oke, 1983; Mepha et al., 2007; Akubugwo et al., 2007).

Amaranthus cruentus has a high nutritional value because of the high contents of vitamins such as $\beta$-carotene (precursor of vitamin A), vitamin B6, vitamin C, riboflavin, and folate, as well as dietary mineral elements including calcium, iron, magnesium, phosphorus, potassium, zinc, copper, and manganese (Makus, 1984; Makus and Davis, 1984; Sussan and Anne, 1988; Stallknecht and Schaeffer, 1993). The vegetable is also rich in lysine, an essential amino acid that is deficient in diets based on cereals and tubers (Schipper, 2000). The vegetable also contain some plant toxins such cyanide, oxalates, nitrate, phytate and other secondary plant metabolites that have negative effect on animals and humans health at high concentrations (Macrae et al., 1997; Ogbadoyi et al., 2011; Musa et al., 2011). The concentrations of the nutrients and toxic substances in vegetables after harvesting are affected by the post-harvest treatment. It is on this basis that the research was conducted to determine the effect of freezing on the concentrations of some phytotoxins and micronutrients in Amaranthus cruentus.

\section{Materials and methods}

\subsection{Source of Amaranthus cruentus}

The fresh samples of Amaranthus cruentus was bought in three sets at different time from Maikunkele, Bosso and Chanchanga markets in Minna town, Nigeria.

\subsection{Chemicals}

Except otherwise stated, all the chemicals used were of analytical grade and were purchased from Sigma and BDH chemical companies, both of England.

\subsection{Freezing}

The leaves of Amaranthus cruentus were washed with distilled water and kept in a well labelled polythene bag and stored in a freezer at the temperature of $-4^{\circ} \mathrm{C}$ for a period of four weeks. The concentrations of the nutrients, antinutrients and toxic substances were determined at weekly intervals over the four - weeks period.

\subsection{Sample analysis}

The nitrate concentration in the samples was determined by the colourimetric method as described by Sjoberg and Alanka (1994). While the alkaline picrate method of Ikediobi et al. 


\section{Macrothink}

(1980) was used to analyse the cyanide content in the leaves of Amaranthus cruentus. Both soluble and total oxalates in the samples were determined by titrimetric method of Oke (1966). The mineral elements ( $\mathrm{Fe}, \mathrm{Cu}, \mathrm{Mg}, \mathrm{Na}$ and $\mathrm{K}$ ) in samples were determined according to the method of Ezeonu et al. (2002). The ascorbic acid concentration in the samples was determined by 2, 6-dichlorophenol indophenols method of Eleri and Hughes (1983). While $\beta$-carotene concentration was determined by ethanol and petroleum ether extraction method as described by Musa et al. (2010).

\subsection{Statistical analysis}

Analysis of variance (ANOVA) was carried out using statistical package Minitab to determine variation between different freezing time on the concentration of nutrients, antinutrients and toxic substances in the leaves of Amaranthus cruentus. The DUNCAN's Multiple Range Test (DMRT) was used for comparison of means.

\section{Results}

\subsection{Cyanide concentration}

The determination of cyanide concentrations in fresh and frozen samples of Amaranthus cruentus showed that the cyanide concentration decreased with freezing. The cyanide concentrations in fresh samples of Amaranthus cruentus decreased significantly $(\mathrm{p}<0.05)$ during one week of freezing from 88.51 to $56.59 \mathrm{mg} / \mathrm{kg}$ (Figure 1). In the subsequent second, third and fourth weeks, the cyanide content also decreased insignificantly with time and the values obtained were 53.27, 52.3 and $46.58 \mathrm{mg} / \mathrm{kg}$, respectively (Fig. 1).

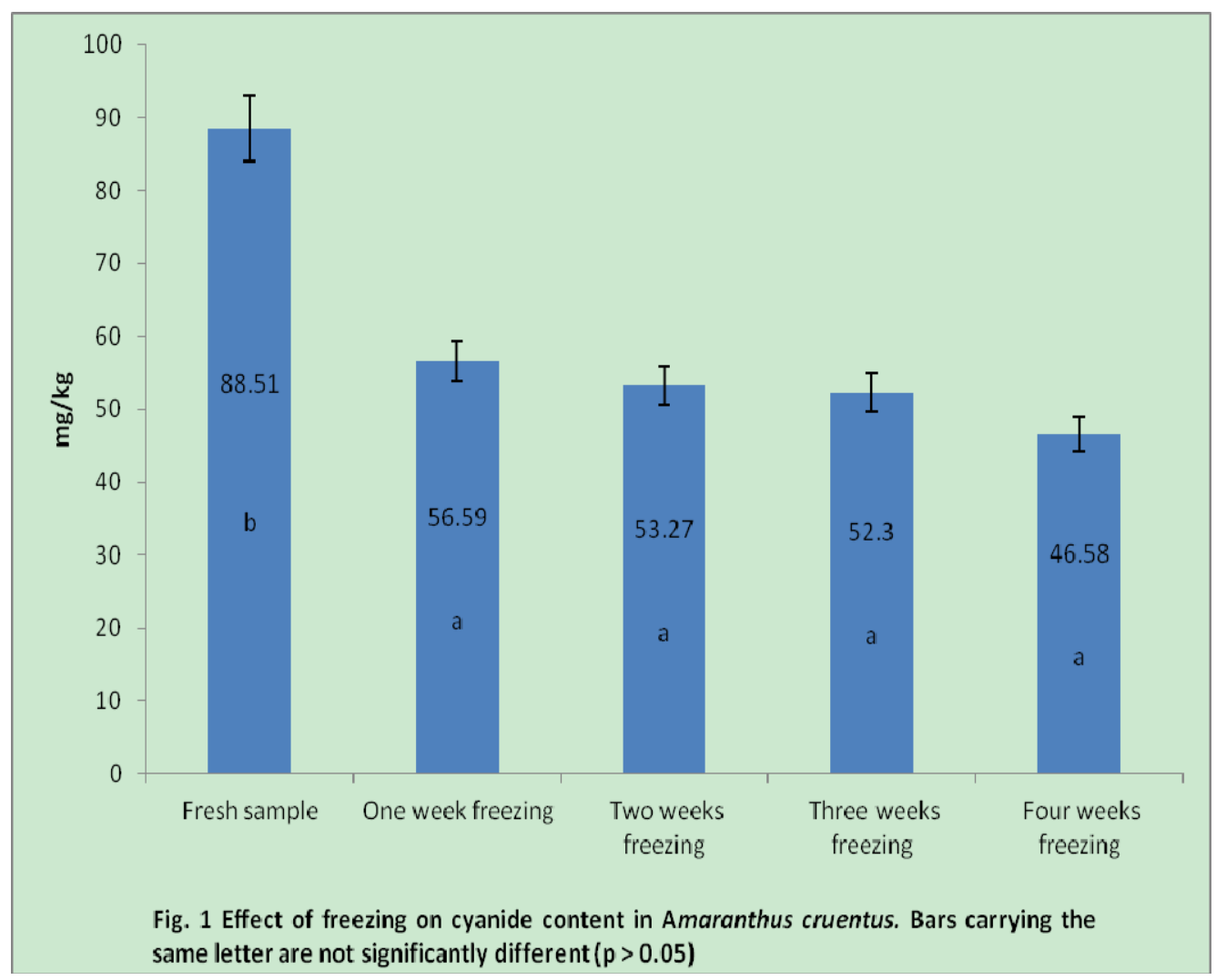




\section{Macrothink}

\subsection{Nitrate concentration}

The concentration of nitrate in the fresh, and those of one, two, three and four weeks frozen samples of Amaranthus cruentus were 4335.22, 4263.33, 3288, 3208.43 and $3149.31 \mathrm{mg} / \mathrm{kg}$, respectively (Fig. 2). The results showed that the decreasing effect of freezing on nitrate concentration in Amaranthus cruentus was not significant in one week of freezing. However, during the second weeks of freezing the nitrate concentration decreased significantly $(\mathrm{p}<$ 0.05). The values obtained for third and fourth weeks of freezing also indicated reduction in nitrate concentration which was not significantly different $(p>0.05)$ from the second weeks of freezing (Fig. 2).

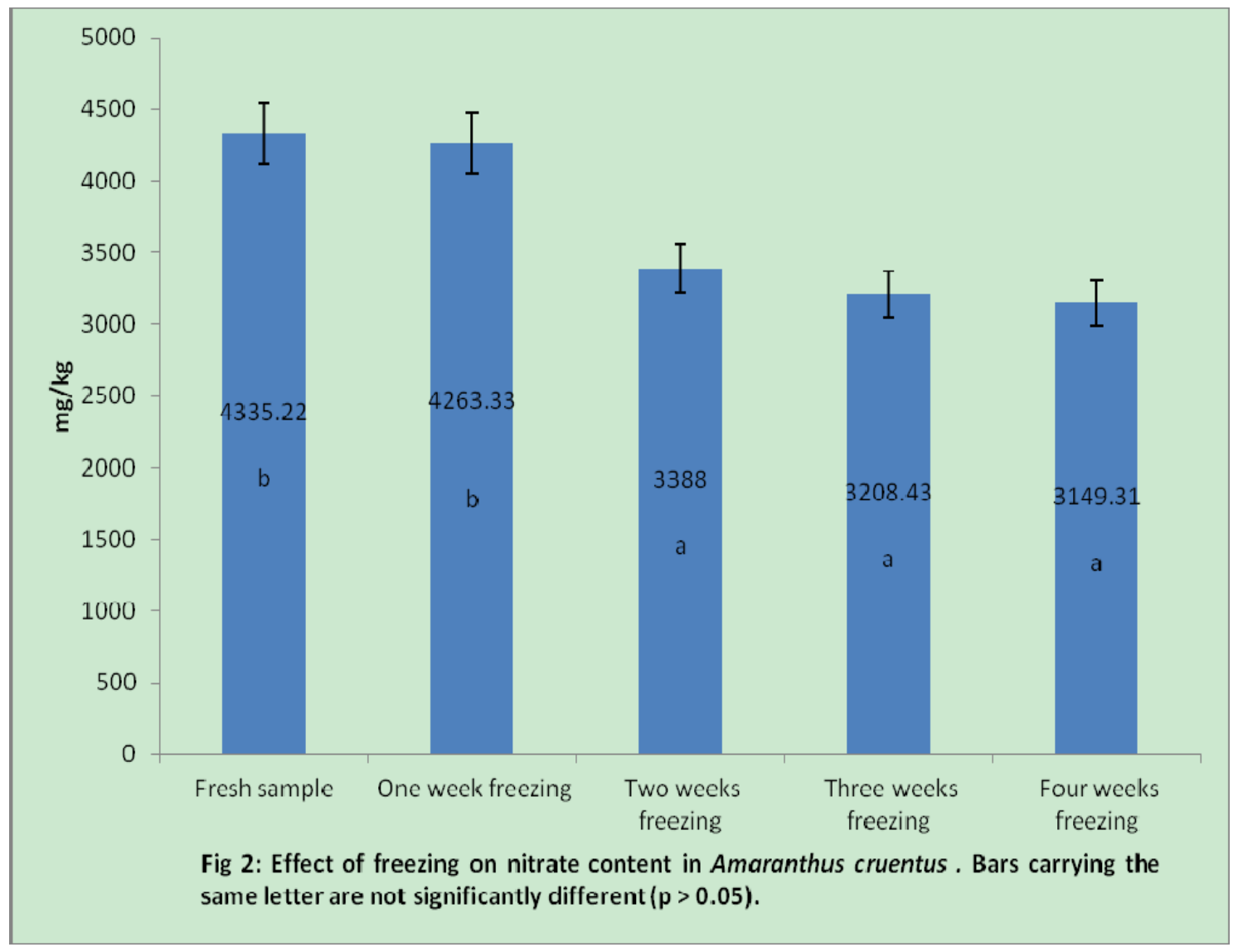

\subsection{Soluble oxalate concentration}

Determination of the effect of freezing on the soluble oxalate content in Amaranthus cruentus showed that the oxalate concentration decreased with freezing time. The soluble oxalate concentration in fresh and those of one, two, three and four weeks frozen samples were 4.02, $3.28,3.28,3.04$ and $2.67 \mathrm{~g} / \mathrm{kg}$, respectively (Fig. 3). The results showed that the soluble oxalate concentration in Amaranthus cruentus decreased significantly $(p<0.05)$ in the first week of storage and remain significantly unchanged $(\mathrm{p}>0.05)$ for second, third and fourth weeks of storage(Fig. 3) 


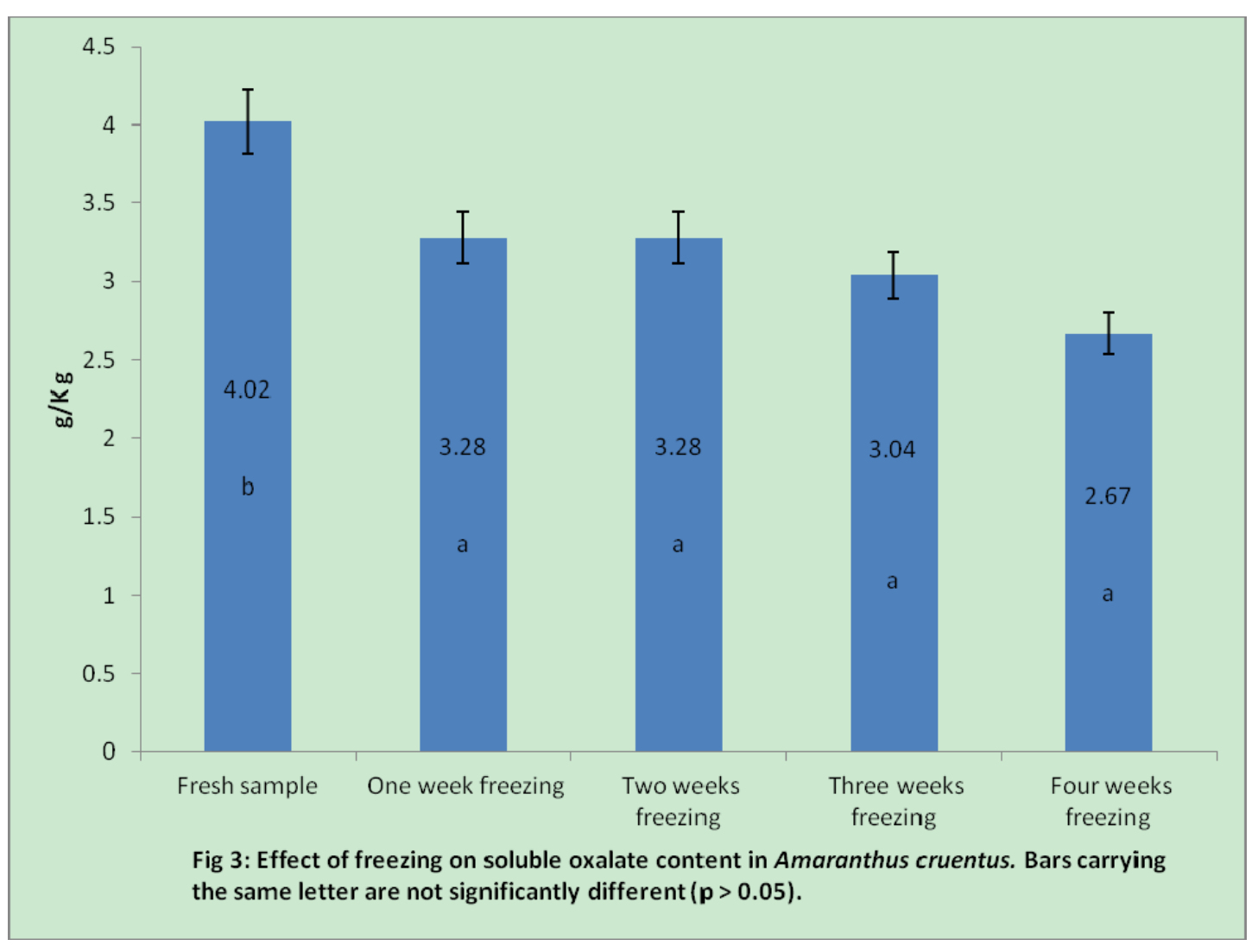

\subsection{Total oxalate concentration}

Analysis of total oxalate concentration in fresh and frozen samples of Amaranthus cruentus showed that the oxalate concentration decreased with freezing time. The total oxalate concentrations in fresh sample of Amaranthus cruentus decreased significantly $(\mathrm{p}<0.05)$ after a week of freezing from 7.99 to $6.27 \mathrm{~g} / \mathrm{kg}$. In the subsequent second, third and fourth weeks, the total oxalate content also decreased insignificantly with time and the values obtained were 6.15, 5.74 and $5.02 \mathrm{~g} / \mathrm{kg}$, respectively (Fig. 4). 


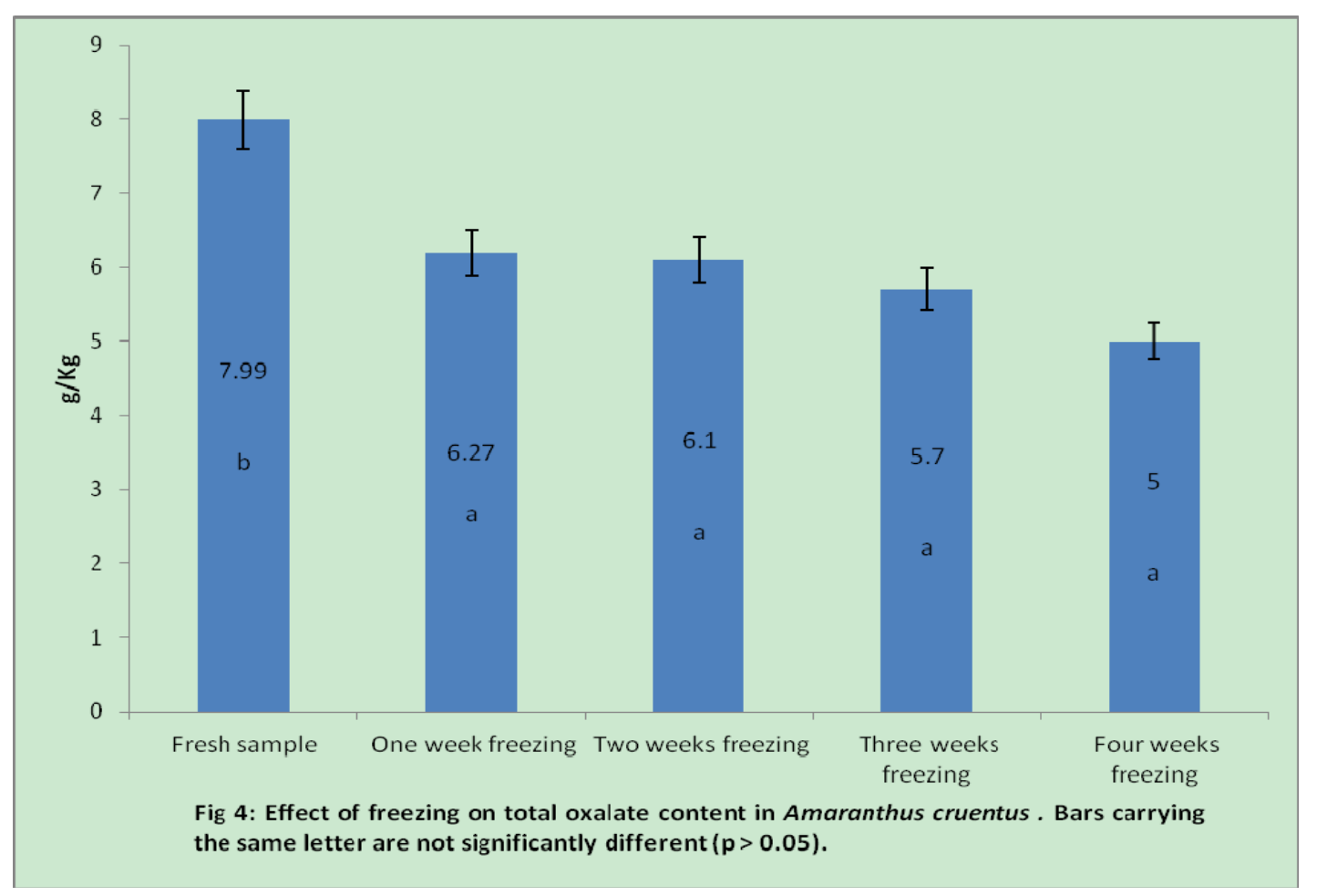

\section{$3.5 \beta$-carotene concentration}

The results obtained from the analysis of $\beta$-carotene concentration in Amaranthus cruentus showed that the carotenoid content decreased with freezing time. Significant reduction $(\mathrm{p}<$ 0.05 ) in the $\beta$-carotene concentration from $11956.80 \mu \mathrm{g} / 100 \mathrm{~g}$ in fresh sample to 9557.00 $\mu \mathrm{g} / 100 \mathrm{~g}$ was observed in one week of freezing. The mean value obtained from the second weeks $(9088.00 \mu \mathrm{g} / 100 \mathrm{~g})$, third weeks $(8381.70 \mu \mathrm{g} / 100 \mathrm{~g})$ and fourth weeks $(7067.30$ $\mu \mathrm{g} / 100 \mathrm{~g}$ ) of freezing also indicated reduction in $\beta$-carotene concentration. While the reduction in the third weeks was not significantly different from second and fourth weeks, the $\beta$-carotene concentration in the fourth weeks of freezing was significantly $(p<0.05)$ lower than second weeks (Fig. 5). 


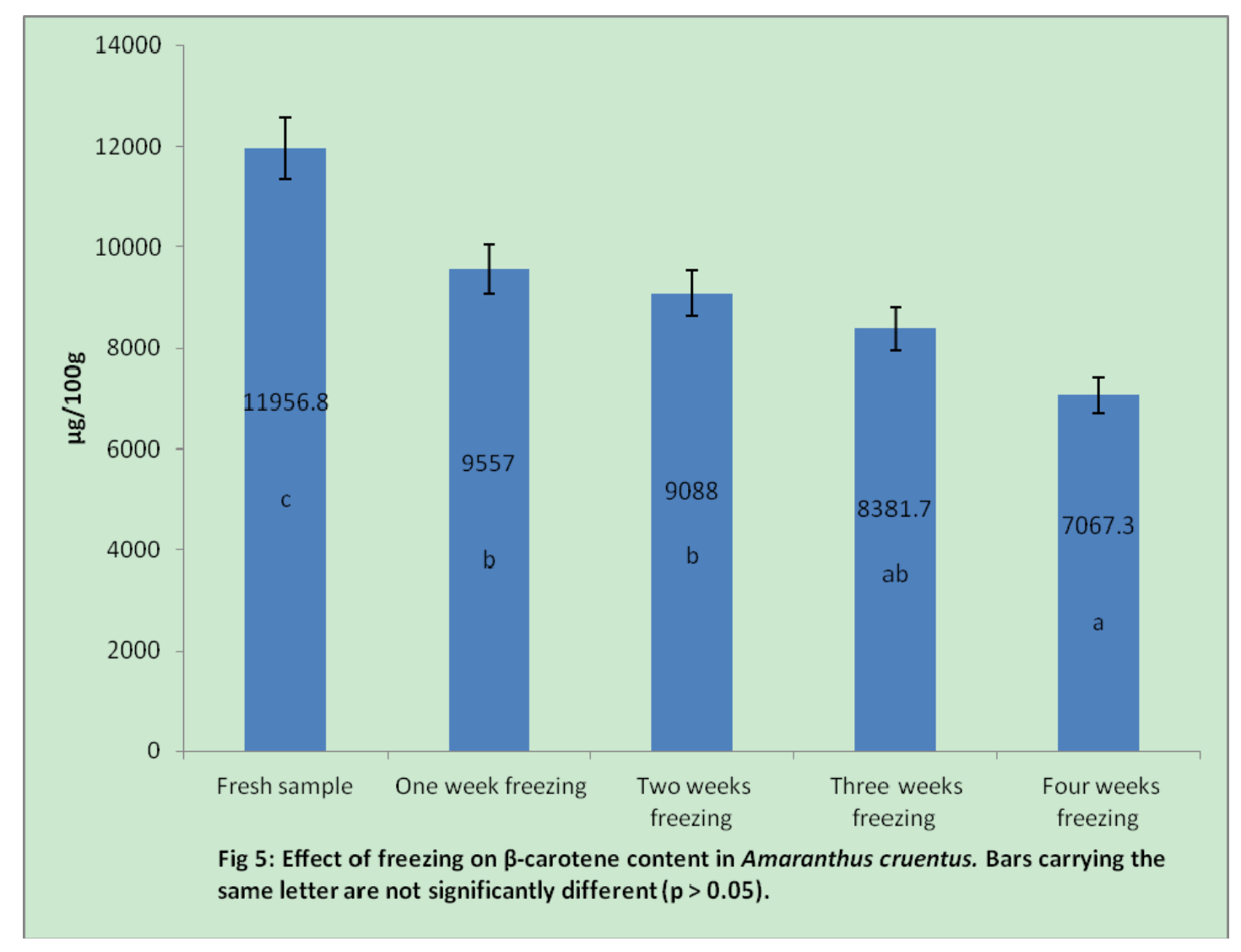

\subsection{Vitamin C concentration}

The vitamin $\mathrm{C}$ concentration in fresh samples of Amaranthus cruentus decreased significantly $(\mathrm{p}<0.05)$ after one week of freezing from 69.35 to $13.34 \mathrm{mg} / 100 \mathrm{~g}$ (Fig. 6). In the second, third and fourth weeks of freezing, the vitamin $\mathrm{C}$ content also decreased insignificantly with freezing time and the values obtained were $11.21,10.14$ and $10.14 \mathrm{mg} / 100 \mathrm{~g}$, respectively (Fig. 6). 


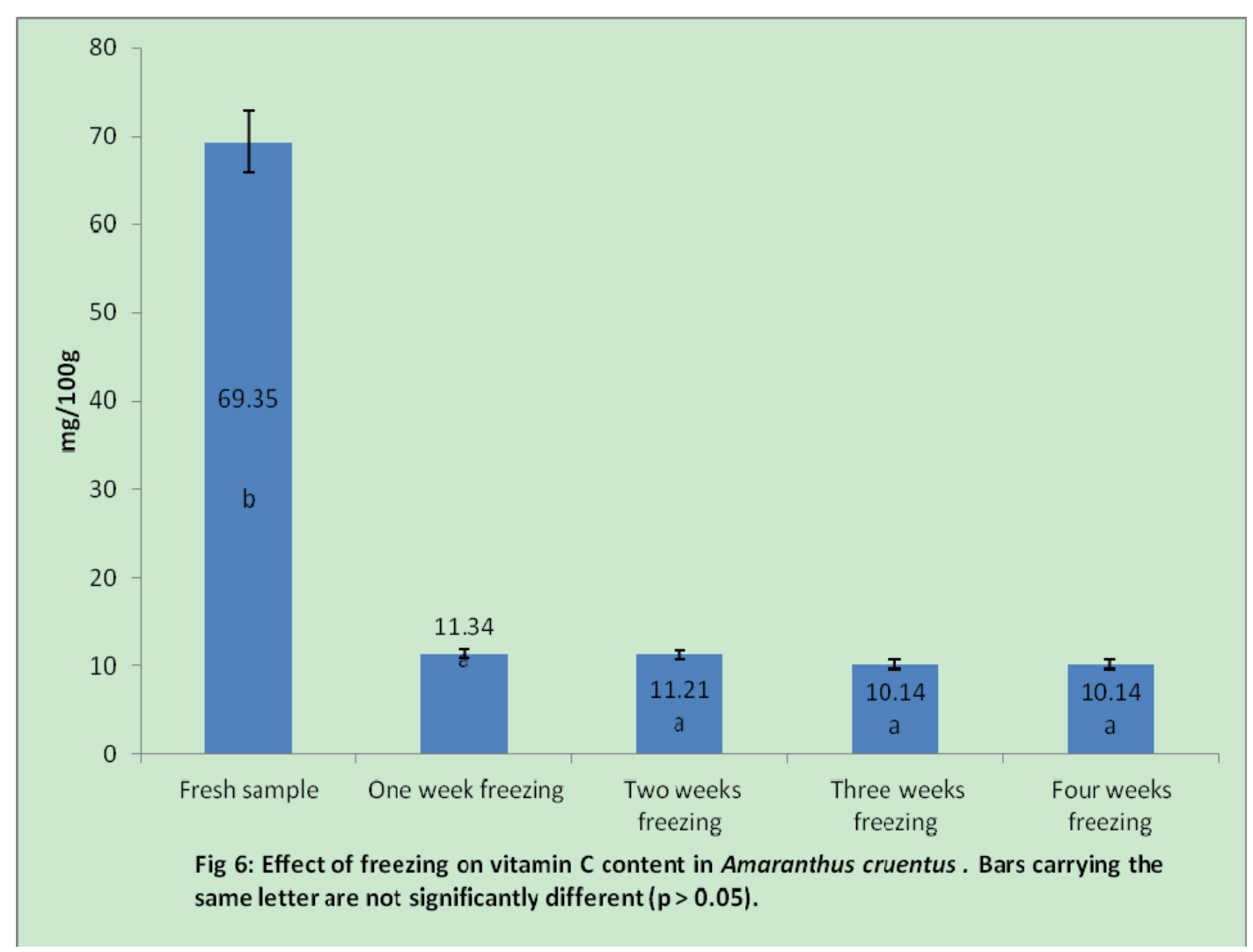

\subsection{Iron Concentration}

Results obtained from the analysis of Fe concentration in fresh and frozen samples of Amaranthus cruentus showed that freezing reduced the mineral content of the vegetables. The concentration of Fe in fresh and samples freezed for one, two, three and four weeks were 19.70, 19.20, 17.08, 14.60 and $13.16 \mathrm{mg} / \mathrm{kg}$, respectively (Fig. 7). The results obtained revealed that the Fe content in the vegetable decreased significantly $(p<0.05)$ in the first week of storage and remain insignificantly $(p>0.05)$ unchanged for second weeks until the third weeks where a significant $(p<0.05)$ decreased was again observed. The decreased in the concentration of Fe recorded in fourth weeks of freezing was insignificant from that of the third weeks (Fig. 7). 


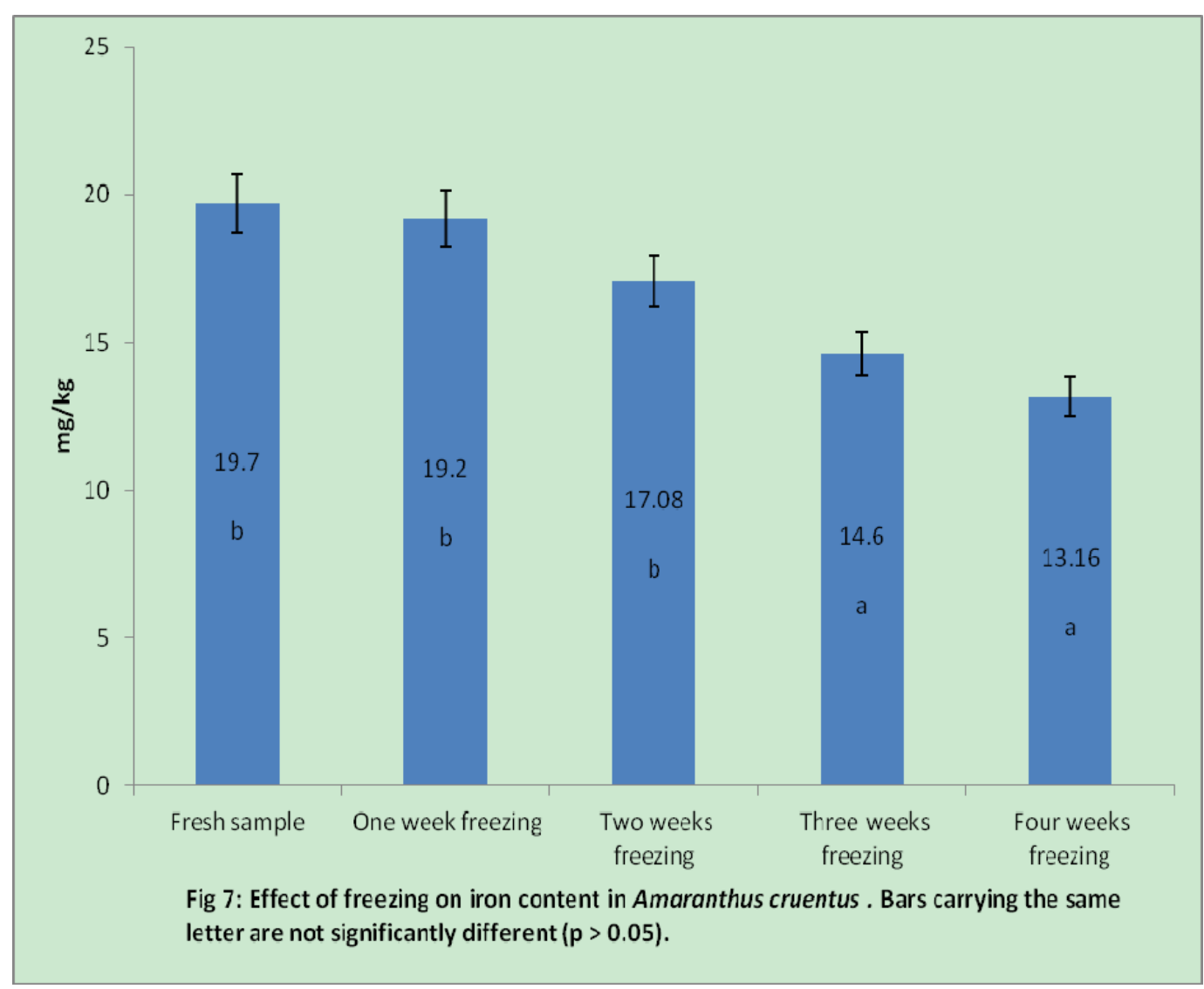

\subsection{Copper Concentration}

The concentration of $\mathrm{Cu}$ in Amaranthus cruentus decreased with freezing storage. Significant $(\mathrm{p}<0.05)$ reduction in the mineral content from $24.24 \mathrm{mg} / \mathrm{kg}$ in fresh sample to $18.89 \mathrm{mg} / \mathrm{kg}$ was recorded after three weeks of freezing. The mean value obtained from the fourth weeks $(18.54 \mathrm{mg} / \mathrm{kg})$ indicated reduction in the $\mathrm{Cu}$ content which was not significantly different from second weeks $(19.4 \mathrm{mg} / \mathrm{kg})$. The $\mathrm{Cu}$ concentration in the first week $(22.22 \mathrm{mg} / \mathrm{kg})$ was however significantly higher $(\mathrm{p}<0.05)$ than those in the third weeks and fourth weeks of freezing (Fig. 8). 


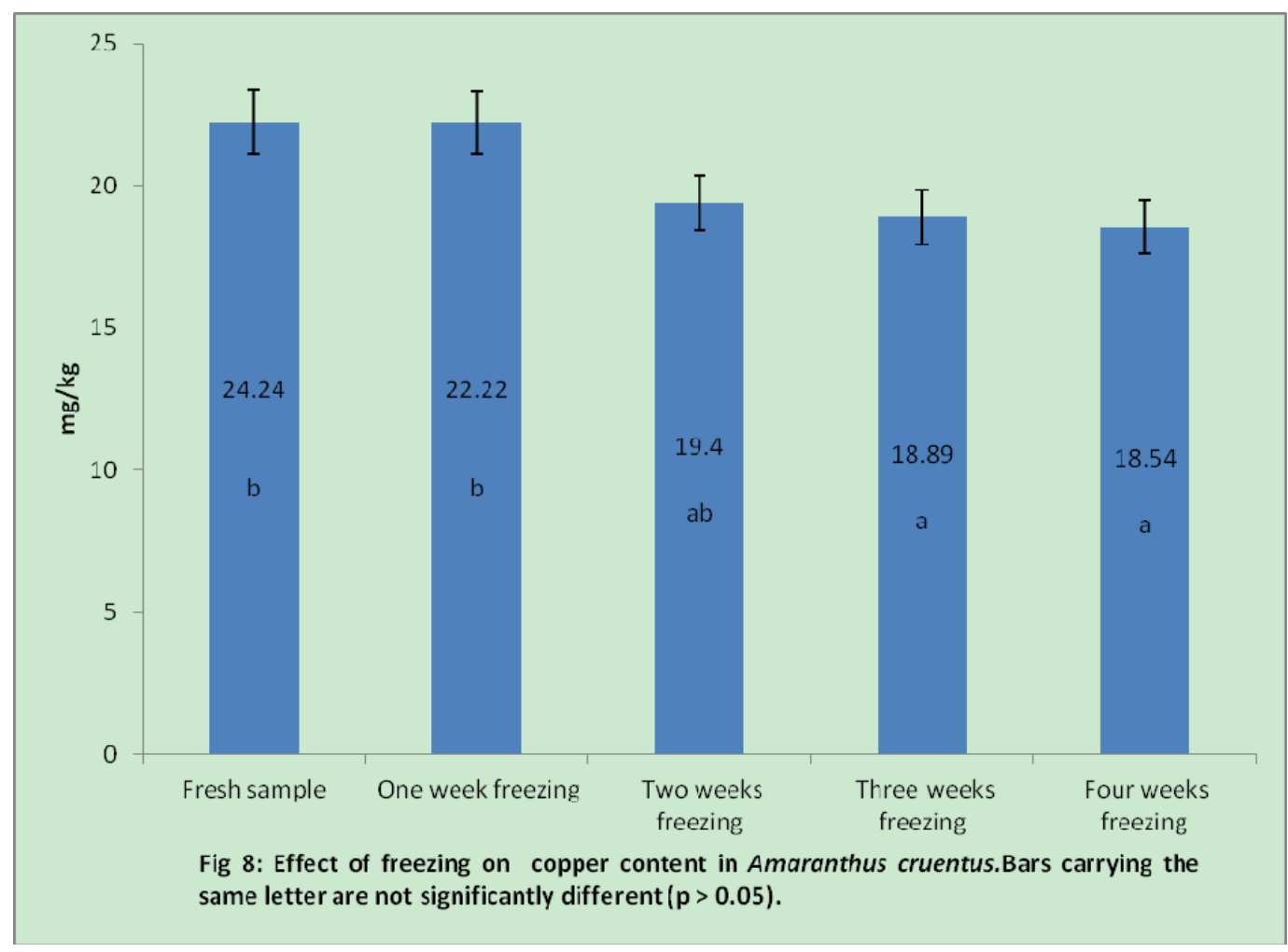

\subsection{Magnesium Concentration}

The concentrations of $\mathrm{Mg}$ in the fresh, and those of one, two, three and four weeks frozen samples in Amaranthus cruentus were 27.78, 26.44, 23.97, 22.90 and $22.21 \mathrm{mg} / \mathrm{kg}$, respectively (Fig. 9). The results showed that the decreasing effect of freezing on $\mathrm{Mg}$ content in Amaranthus cruentus was not significant in one week of freezing. However, after two weeks of freezing the mineral element concentration decreased significantly $(p<0.05)$. The values obtained for third and fourth weeks of freezing also indicated reduction in $\mathrm{Mg}$ content which was not significantly ( $p>0.05$ ) different from the second weeks (Fig. 9). 


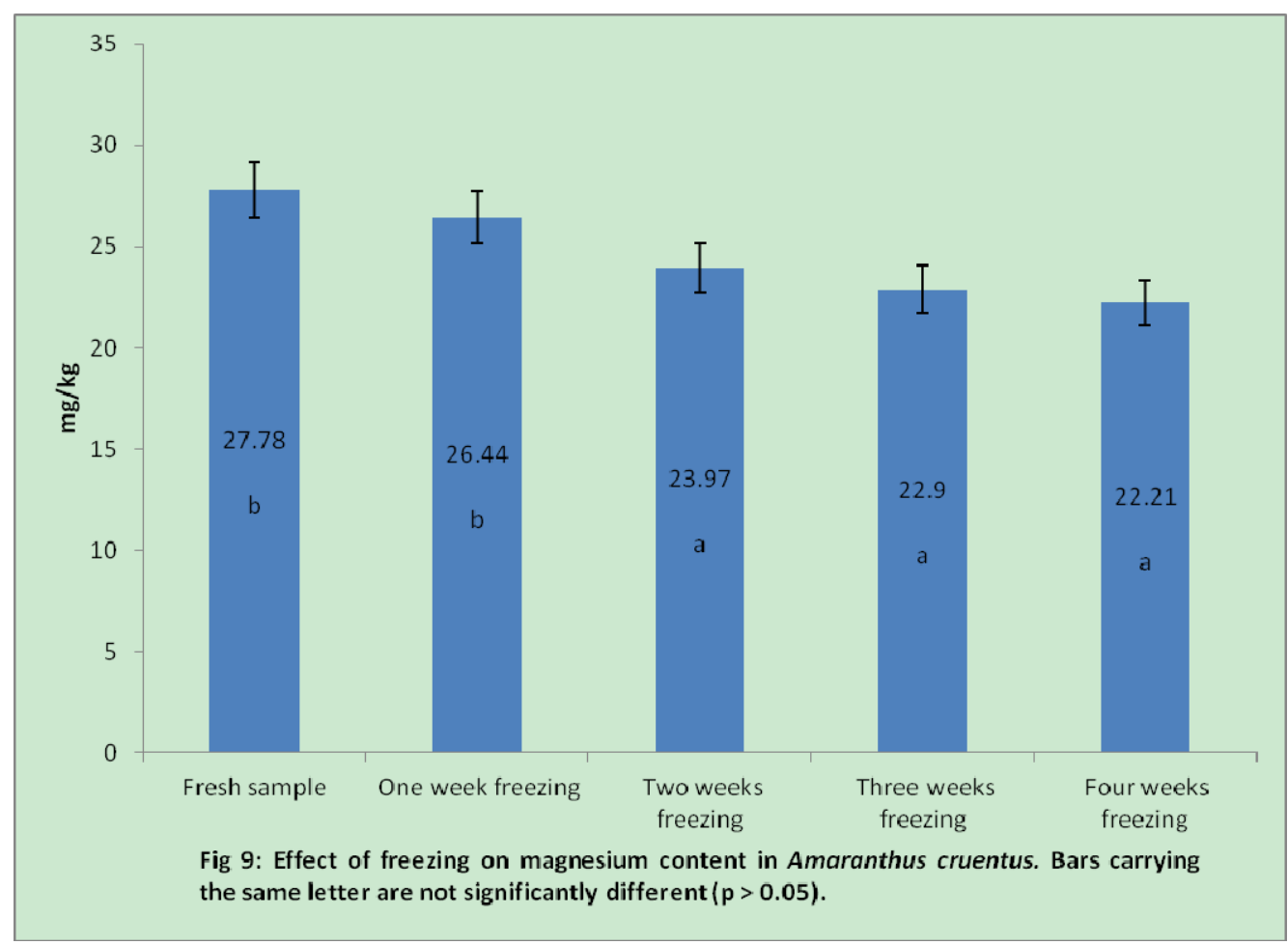

\subsection{Sodium Concentration}

The concentrations of $\mathrm{Na}$ in the fresh sample of Amaranthus cruentus $(12.30 \mathrm{mg} / \mathrm{kg}$ ), and those samples frozen for one week $(11.50 \mathrm{mg} / \mathrm{kg})$, two weeks $(10.50 \mathrm{mg} / \mathrm{kg})$, three weeks $(9.90 \mathrm{mg} / \mathrm{kg})$ and four weeks $(9.53 \mathrm{mg} / \mathrm{kg})$ showed that freezing had no significant effect on the mineral content in the vegetable in one week of freezing. However, with two weeks of freezing, the $\mathrm{Na}$ content decreased significantly $(\mathrm{p}<0.05)$. The mean values obtained for third and fourth weeks of freezing also indicated reduction in $\mathrm{Na}$ content which was not significantly $(\mathrm{p}>0.05)$ different from the second weeks (Fig. 10). 


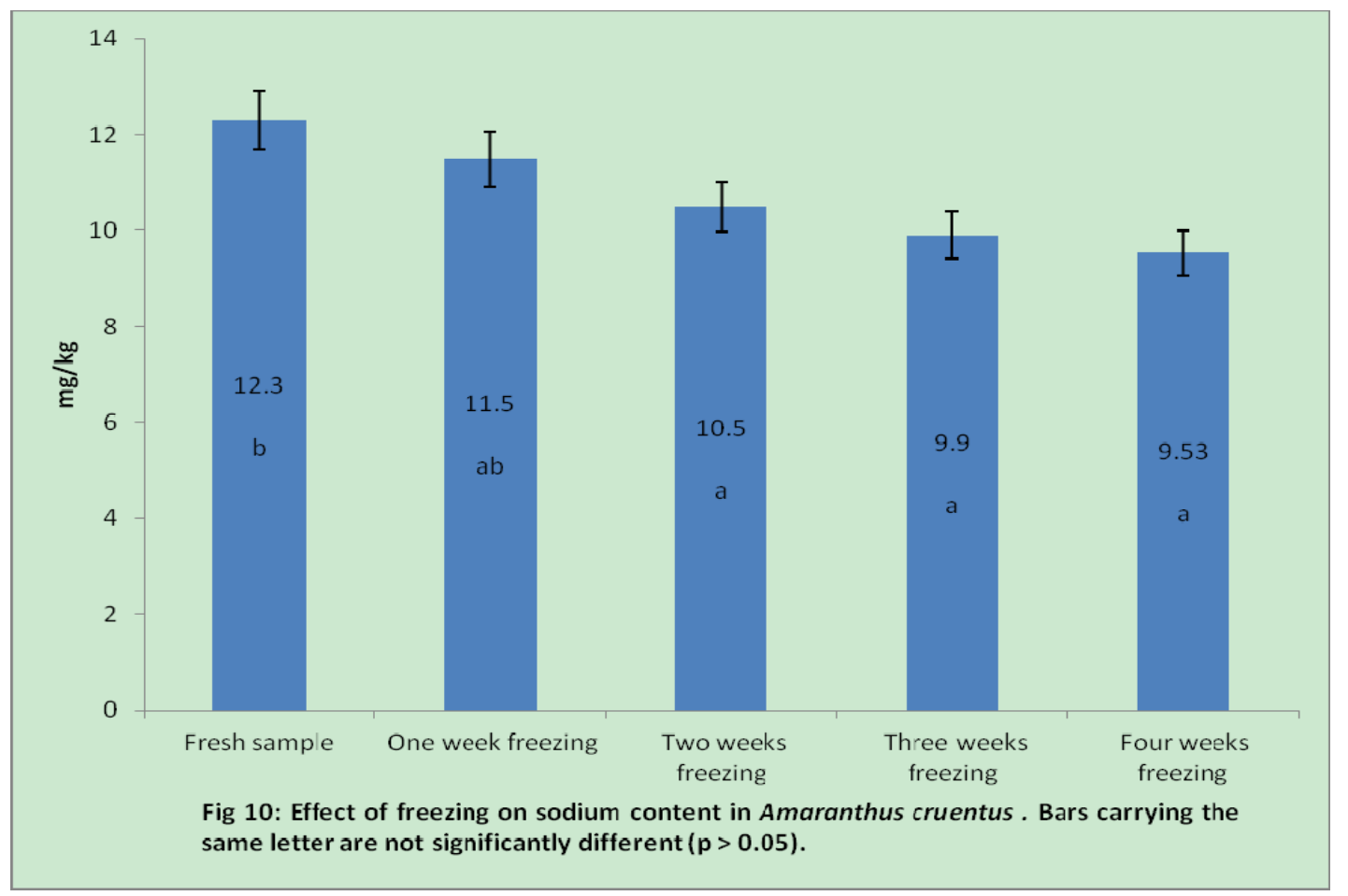

\subsection{Potassium Concentration}

The amount of $\mathrm{K}$ in the fresh and frozen samples of Amaranthus cruentus for one, two, three and four weeks were $241.88 \mathrm{mg} / \mathrm{kg}, 192.92 \mathrm{mg} / \mathrm{kg}, 187.50 \mathrm{mg} / \mathrm{kg}, 174.40 \mathrm{mg} / \mathrm{kg}$ and 159.78 $\mathrm{mg} / \mathrm{kg}$, respectively. The results obtained showed that freezing significantly $(\mathrm{p}<0.05)$ decreased the $\mathrm{K}$ content in the first week and the values remain significantly unchanged throughout the fourth weeks of storage period (Fig. 11). 


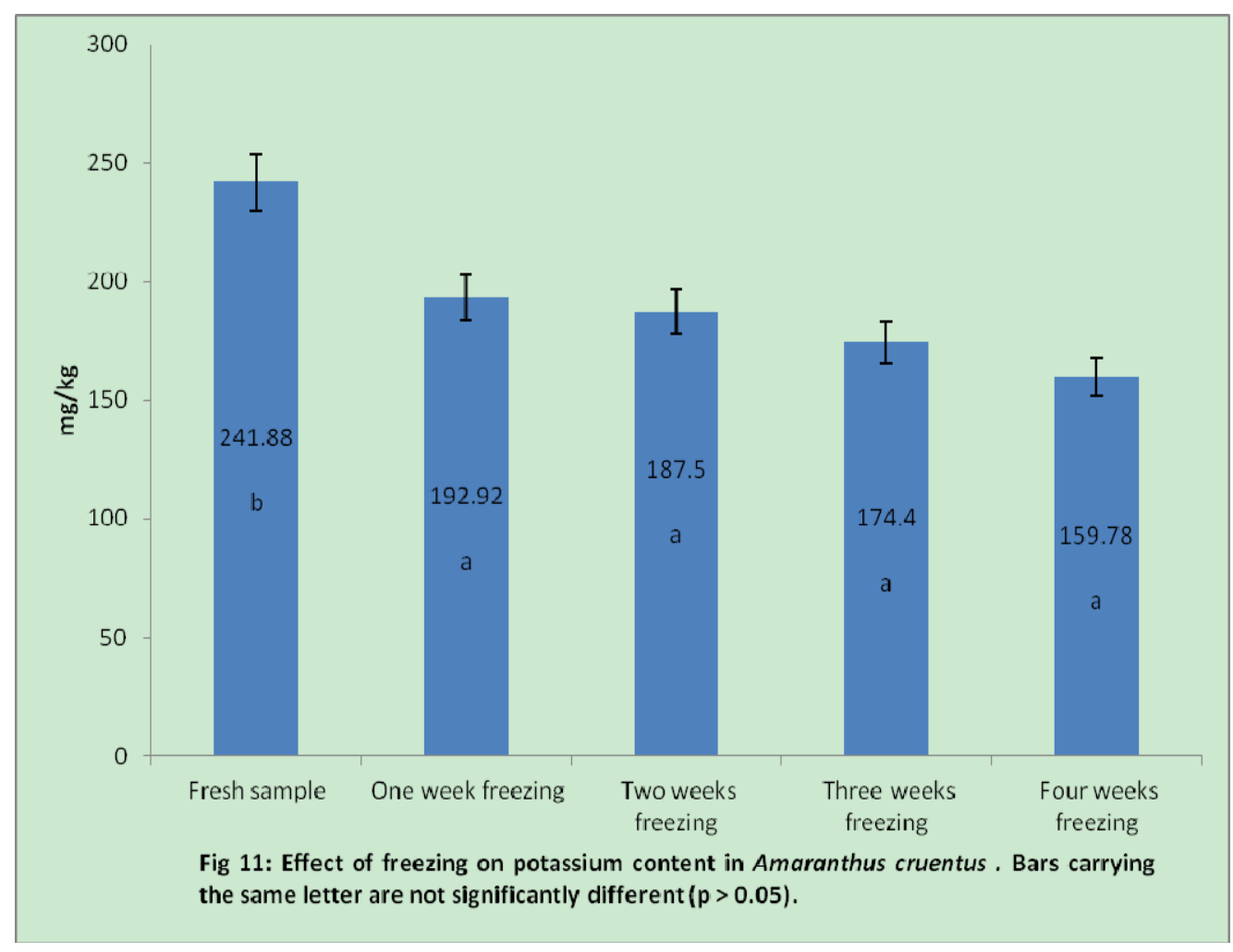

\section{Discussion}

The decreasing effect of freezing on cyanide, nitrate, soluble and total oxalates, $\beta$-carotene, vitamin $\mathrm{C}$ and mineral elements $(\mathrm{Fe}, \mathrm{Cu}, \mathrm{Mg}, \mathrm{Na}$ and $\mathrm{K}$ ) concentrations observed in the leaves of Amaranthus cruentus corroborates with the reported of following researchers (Richard, 1991; Booth, 1992; Olaofe, 1992; Yadav and Sehgal, 1995; Abakr and Ragaa, 1996; Polo et al., 1997; Pruthi, 1999; Yadav and Sehgal, 1997; Fellow, 2000; Lisiewka and Kmiecik, 2000; Hui et al., 2004; Ejoh et al., 2005; Berguist et al., 2006; McDonald et al., 2006; Ogbadoyi et al., 2006; Piotr et al., 2006). These authors reported that freezing ruptures the plant cells which result in the release (leaching) of antinutrients and nutrients content of the cell. Budavaris et al. (1989) also stated that the decrease in cyanide during freezing may be attributed to the solubility of the compound in water. Thus cyanide may be trapped in the ice and released during thawing. Ogbadoyi et al. (2006) further stressed that freezing of tissues at high moisture content results in the formation of ice crystals within the cells. The sharp edges of the crystals so formed are capable of lacerating the cell membranes resulting in cell leakage and its contents. Similarly Booth et al. (1992) noted that, in addition to cell ruptures and leaching that occur during freezing, the observed decrease in the $\beta$-carotene concentration could be as a result of enzymatic activity coupled with oxidation associated with conjugate double bond in the compound. Olaofe (1992) on the other hand, reported that decreased in vitamin $\mathrm{C}$ concentration during refrigerated storage is partly due to the enzymatic activities of vitamin $\mathrm{C}$ oxidase, cytochrome oxidase and vitamin $\mathrm{C}$ peroxidase that were endogenously present. The findings agreed with the report of Bergquist et al. (2006) that during freezing of vegetables the ascorbic acid concentration decreased considerably and the dehydroascorbic acid/vitamin $\mathrm{C}$ ratio increased. The generally insignificant differences 
recorded in the $\beta$-carotene concentration in second to fourth weeks and vitamin $\mathrm{C}$ content in first to fourth week of storage could be seen as a result of decrease in endogenous enzymatic activity and reduction of oxidation of the compound as freezing storage progresses.

The mineral concentrations in vegetables depend on species, cultivar, plant age, production techniques, and post harvest handling, beside other environmental factors (Chweya and Nameus, 1997; Lisiewska et al., 2006; Rickman et al., 2007). The observed declined in the minerals ( $\mathrm{Fe}, \mathrm{Cu}, \mathrm{Mg}, \mathrm{Na}$ and $\mathrm{K}$ ) concentration in Amaranthus cruentus with freezing time indicated that freezing generally decreases the mineral concentration of the vegetable. The reason for this could be attributed to the fact that freezing can damage some foods (especially salad vegetable, mushrooms and soft fruits) because the formation of ice crystals during freezing causes the breakage of the cell membranes. Freezing is also known to inflict physical injuries to the cell wall and as well as alteration of plant pigments, which are sources of bioactive compounds. All these processes lead to the release of cell content including some of the mineral content (Polo et al., 1997; Pruthi, 1999; Fellow, 2000; Hui et al., 2004; McDonald et al., 2006). "Freezer burn" which occurs during freezing of vegetables and other soft plant materials is known to decrease the bioactive compounds including the mineral elements.

\section{Conclusion}

This study revealed that even though the concentration of plant toxins (cyanide, nitrate and oxalates) in Amaranthus cruentus decreased significantly with freezing, the nutrient contents of the vegetable were also compromised.

\section{References}

Abakr, A., \& Ragaa, A. (1996). Trials to reduce nitrate and oxalate content in some leafy vegetables; Interactive effect of manipulating of the soil nutrient supply, different blanching media and preservation methods followed by cooking process. Journal Science Food Agriculture, 97, 169-178.

Akubugwo, I.E., Obasi, N.A., Chinyere, G.C., \& Ugbogu, A.E. (2007). African Journal of Biotechnology, 6(24), 2833-2839.

Bergquist, S.A.M., Gertsson, U.E., \& Olsson, M.E. (2006). Influence of growth stage and postharvest storage on ascorbic acid and carotenoid content and visual quality of baby spinach (Spinacia oleracea L.). Journal of the Science of Food and Agriculture, 86(3), 346-355. http://dx.doi.org/10.1002/jsfa.2373

Booth, L. S., Johns, T., \& Kuhnlein, H. V. (1992). Natural food sources of vitamin A and provitamin A; Difficulties with the published values. United Nations University Press. Food and Nutrition Bulletin, 14(1), 2 - 13

Budavari, S., Oneil, M.J., \& Smith, A. (1989). The merck index. Merck and Co. Inc. Rahway. NJ. Pp 4722.

Chweya, J.A., \& Nameus, A.M. (1997). Cats whiskers (Cleome gynandra L). Promoting the 
conservation and use of underutilized and neglected crops. 11. Institute of plant genetics and crop plant research. Gatersleben / International plant Genetic Resources Institute, Rome, Italy. Pp 18 - 21.

Dhellot, J.R., Matouba, E., Nzikou, J.M., Safou, D.G., Linder, N.M., Desobry, S., \& Parmentier, M. (2006). Extraction, chemical composition and nutritional characterization of vegetable oils: Case of Amaranthus hybridus (Vol 1 and 2) of Congo Brazaville. African Journal of Biotechnology, 5(11), 1095 - 1101.

Ejoh, A.R., Tanya, A.N., Djuikwo, N.A., \& Mbofung, C.M. (2005). Effect of processing and preservation methods on vitamin $\mathrm{C}$ and total carotenoid levels of some Vernonia (bitter leaf) species. African Journal of Food Agriculture Nutrition and Development, 5(2), 105-117.

Eleri, T. and Hughes, R.E. (1983). Foliar ascorbic acid in some Angiosperms. Phytochemistry. 2 (11): 2493.

Ezeonu, F.C., Musa, A., Stanly, C.D., \& Oswald, C.E. (2002). Iron and zinc status in soils, water and stable food cultivars in Itakpe, Kogi state of Nigeria. The Environmentalist, 22, 237-240. http://dx.doi.org/10.1023/A:1016527828814

Fellows, P.J. (2000). Food processing technology; Principles and practice. Wood Publishing Limited. Pp 60 - 63. http://dx.doi.org/10.1201/NOE0849308871

Grubben, G.J.H. (1986). The cultivation of amaranth as a tropical leafy vegetables communication (67). Department of Agricultural Research. Royal Tropical Institute Amsterdam. Pp 11-12.

He, H.P., Cai, Y., Sun, M., \& Corke, H. (2002). Extraction and purification of squalene from amaranthus grain. Journal of Agriculture and Food Chemistry, 50(2), 368-372. http://dx.doi.org/10.1021/jf010918p

Hui, Y.H., Puil, C., Isabel, G.L., Miang, H.L., Murrell, K.D., \& Wai - kit, N. (2004). Hand book of frozen foods. Marcel Dekker Incorporated. Pp $74-75$.

Ikediobi, C.O., Onyia, G.O.C., \& Eluwah, C.E. (1980). A rapid and inexpensive enzymatic assay for total cyanide in cassava (Manihot esculenta crantz) and cassava product. Agriculture and Biological Chemistry, 44, 2803-2808. http://dx.doi.org/10.1271/bbb1961.44.2803

Lisiewska, Z., \& Kmiecik, W. (2000). Effect of storage period and temperature on the chemical composition and organoleptic quality of frozen tomato cubes. http; //www. Science direct.com / science? - ob $=$ Article URL \& - Udi $=$ B6T6R - 40PXMM8 - $6 \&$ - US.

Lisiewska, Z., Kmiecik, W., \& Gebczynski, P. (2006). Effect on mineral content of different methods of preparing frozen root vegetables. Food Science and Technology International, 12(6), 497-503. http://dx.doi.org/10.1177/1082013206073273

Macrae, R., Robinson, R.K., \& Sadler, M.J. (1997). Encyclopaedia of Food Science, Food Technology and Nutrition. New York, Academic Press. 5, 3240-3249, 7:4715-4757. 
Makus, D.T., \& David, D.R. (1984). A mid-summer crop for fresh green or canning-vegetables amaranth. Ark. Farm Resources. May - June. Pp $1-4$.

Makus, J.D. (1984). Evaluation of amaranth as a potential green crop in the mid-south. Horticultural Science, 19, $881-883$.

Mc Donald, J.k., Caflin, N.A., Sommano. S., \& Cocksedge, R. (2006). The Effect of post harvest handling on selected native food plant; A report for the rural Industries Research and Development Corporation. Pp $1-13$.

Mepha, H.D., Eboh, L., \& Banigbo, D.E.B. (2007). Effect of processing treatments on the nutritive composition and consumer acceptance of some Nigerian edible leafy vegetables. African Journal of Food Agricultural Nutrition Development, 7(1), 1 - 18.

Musa, A., Ezenwa, M.I.S., Oladiran, J. A. and Akanya, H.O. and Ogbadoyi, E.O., (2010). Effect of soil nitrogen levels on some micronutrients, anti-nutrients and toxic substances in Corchorus olitorius grown in Minna, Nigeria. African Journal of Agricultural Research, 5 (22), 3075-3081. http://www.academicjournals.org/AJAR.

Musa, A., Oladiran, J. A., Ezenwa, M.I.S. and Akanya, H.O. and Ogbadoyi, E.O., (2011). Effects of applied nitrogen fertilizer and leaf positions on the levels of micronutrients, anti-nutrients and toxic substances in Amaranthus cruentus. African Journal of Biotechnology, 10 (48), 9857-9863. http://www.academicjournals.org/AJB.

Ogbadoyi, E.O., Makun, A.H., Bamigbade, O.R., Oyewale, O.A., \& Oladiran, J.A. (2006). The effect of processing and preservation methods on the oxalate levels of some Nigeria leafy vegetables. Biokemistri, 18(2), 121-125. www.bioline.org.br/request

Ogbadoyi, E.O., Musa, A., Oladiran, J. A., Ezenwa, M.I.S., \& Akanya, H.O. (2011). Effect of processing methods on some nutrients, antinutrients and toxic substances in Amaranthus cruentus. International Journal of Applied Biology and Pharmaceutical Technology, 2(2), 485-502. http://www.ijabpt.com.

Oke, L.O. (1966). Chemical Composition of some Nigeria leafy vegetables. Journal of American Dietetic Association, 53, 130 - 132.

Oke, O.L. (1983). Amaranthus In "Handbook of tropical foods" Chan Jr, H.T. Edition. Marcel-Dekker, Inc. New York. Pp $1-2$.

Olaofe, O. (1992). Vitamin C content of Nigerian food - stuffs. Nigerian Journal of Nutritional Science, 13(1, 2), 1-7.

Piotr, G. (2006). Content of selected antioxidative compounds in raw carrot and in frozen product prepared for consumption. Electroninic Journal of Polish Agricultural Universities. (http; //www. Ejpau. Media. Pl /volume 9/ issue3/ art--03-html).

Polo, M. V., Lagarda, M. J., \& Farre, R. (1997). The effect of freezing on mineral element content of vegetables. Journal of Food Composition and Analysis (USA), 5(1), 77-83. http://dx.doi.org/10.1016/0889-1575(92)90008-8 


\section{Macrothink

Pruthi, J. S. (1999). Quick freezing preservation of foods; Principles, practices. R and D needs. Allied Publishers (Idian). Pp 442 - 443.

Richard, D.W. (1991). Cooperative Extension Service: Cooperative Extension work acts may 8 and June 30, 1914, as amended, Kansas State University, County Extension Councils. Extension Districts and U.S. Department of Agriculture Cooperating.

Rickman, J. C., Bruhn, M. C., \& Barret, D. M. (2007). Nutritional comparison of fresh, frozen and canned fruits and vegetables ii. Vitamin A and caroteniods, Vitamin E, minerals and fiber. Journal of Science, Food and Agriculture, 88, 1185-1196. http://dx.doi.org/10.1002/jsfa.2824

Schippers, R.R. (2000). African indegenous vegetables: An overview of the cultivated species. University Greenwwish. England. pp 193 - 205.

Sjoberg, A.M.K., \& Alanka, T.A. (1994). Spectrophotometric determination of nitrate in baby food: Collaborative study. Journal of AOAC International, 77(2), 425-430.

Stallknecht, G.F., \& Schulz-Schaeffer, J.R. (1993). Amaranth rediscovered. In. J. Janick and J.E. Simon eds. New Crops. Wiley Crops Wiley, New York. Pp $32-37$.

Sussan, M., \& Anne, P. (1988). Tropical and sub-tropical food. $2^{\text {nd }}$ edition. Macmillan Publisher. England. Pp 102 - 106.

Yadav, S. K., \& Sehgal, S. (1995). Effect of home processing on ascorbic acid and beta-carotene content of spinach (Spinacia oleracia) and amaranth (Amaranthus tricolor) leaves. Plant Foods for Human Nutrition, 47(2), 125-131. http://dx.doi.org/10.1002/jsfa.2824

Yadav, S.K., \& Sehgal, S. (1997). Effect of home processing and storage on ascorbic acid and beta-carotene content of bathua (Chenopodium album) and fenugreek (Trigonella foenum graecum) leaves. Plant Foods for Human Nutrition, 50(3), 239-247. http://dx.doi.org/10.1007/BF02436060 